gambling companies and now allow longer opening hours for betting shops and for the shops to look more attractive, advertising of football pools, and a lower age limit at which people can play the pools. ${ }^{10}$ This combination of measures has been associated with a reported increase of $17 \%$ in calls to Gamblers Anonymous. ${ }^{17}$

The sheer scale of expenditure on the National Lotteryover $£ 100 \mathrm{~m}$ a week, of which over $£ 40 \mathrm{~m}$ is spent on scratch cards-gives it the potential to be a major force for good or evil. There is an urgent need for detailed research on its \footnotetext{
1 Thorncroft A. Lottery grant of $£ 13 \mathrm{~m}$ secures Churchill papers. Financial Times 1995 Apr 27:12.
2 McKinnon A. Lottery loser killed himself for just $£ 27$. Independent 1995 Jun 16:7.

3 Purnell S. MPs attack $£ 20 \mathrm{~m}$ bill to distribute lottery cash. Daily Telegraph 1995 Jun 9:3.

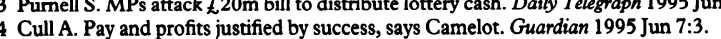

5 Muir H. Lottery's $£ 18 m$ winners fight to save marriage. Daily Telegraph 1995 Jul 17:5.

6 Wilkinson RS. National mortality rates: the impact of inequality. Am $\mathcal{F}$ Public Health 1992;82: $1082-4$.

7 Benzeval M, Judge K, Whitehead M. Tackling inequalities in health. London: King's Fund 1995.

8 Phillimore P, Beattie A, Townsend P. Widening inequality of health in northern England 1981-91. $B M 7$ 1994;308:1125-8.

9 Life's a gamble. Economist 1994 Nov 19:17.
}

redistributive effects and its impact on family expenditure. Anything that makes poor people in Britain even poorer, especially if they do not derive benefits in kind, becomes an important public health issue.

MARTIN McKEE Reader in public health medicine

FRANCO SASSI

Health economist

Health Services Research Unit,

London School of Hygiene and Tropical Medicine,

London WC1E 7HT

\footnotetext{
10 FitzHerbert L. Winners and losers. The impact of the National Lottery. York: Joseph Rowntree Foundation, 1995.

11 Kentsmith E, Thomas S. Luck had nothing to do with it-launching the UK's largest consumer brand. Fournal of the Market Research Society 1995;37:127-41.

12 Weinstein $\mathrm{D}$, Deitch L. The impact of legalized gambling: the socioeconomic consequences of lotteries and off-track betting. New York: Praeger, 1978 .

13 Brown DJ, Kaddenburg DO, Browne BA. Socioeconomic status and playing the lotteries. Sociology and Social Research 1992;76:161-7.

14 Mikesell JL. State lottery sales and economic activity. National Tax fournal 1994;47:165-71.

15 Devereux EC. Gambling and the social structure. New York: Amo, 1980.

16 Ellison M. Royal Opera's lottery grant sparks cash for "tolls" row. Guardian 1995 Jul 21:3.
}

17 Tresidder M. Mr Nice Guy won the lottery. ... Guardian 1995 Jun 10:27.

\title{
Pathological gambling
}

\section{An addiction to an altered psychological state}

Neither gambling nor its problems are new to human history. Artefacts related to gambling dating from $3000 \mathrm{BC}$ have been identified in the remains of ancient Babylon. Lotteries originated in Europe in the middle ages, and the first lottery to be sponsored by a government was chartered by Queen Elizabeth I of England in 1566.' Serious gambling problems are described in the classical literature of many cultures, such as the Hindu epic the Mahabharata. The Russian novelist Dostoevsky wrote his 1866 novella The Gambler in a desperate effort to repay his own gambling debts. ${ }^{2}$ Yet despite the accelerating trend towards the legalisation of many types of wagering worldwide and the awareness that for some people gambling becomes a destructive addiction, little attention has been given to the prevention or treatment of its problems.

Gambling is big business in the United States, with about $\$ 330000$ million ( $£ 220000$ million) wagered in $1992 .{ }^{3}$ Problems due to gambling are also widespread. The lifetime prevalence of pathological or compulsive gambling among the adult population in the United States is between about 3.5\% and $6.3 \%{ }^{4}$ The current prevalence is between $1.4 \%$ and $2.8 \% .^{5}$ The disorder is more common in patients being treated for alcohol and other drug dependence, with a lifetime prevalence of $9 \%$ among adults and $14 \%$ among adolescent inpatients. ${ }^{67}$ Although research into the epidemiology of this disorder is relatively recent, there are some indications that rates have risen in the United States with increases in the availability of gambling. ${ }^{5}$

Pathological gambling was first included in the official Diagnostic and Statistical Manual of Mental Disorders of the American Psychiatric Association in 1980. During the past 15 years its diagnostic criteria have been refined, ${ }^{4}$ and a paper and pencil screening tool has become available for identifying gambling in general and clinical populations. ${ }^{89}$

Although pathological gambling has been conceptualised in several theoretical frameworks, it is widely understood as an addiction to the altered psychological state experienced while the gambler is in action. This state is described as a high similar to the effect of a stimulant drug and also as a feeling of dissociation permitting an escape from worries. The sensation may relate to increases in noradrenaline both peripherally and in the central nervous system. ${ }^{1}$ As the disorder progresses the pathological gambler is increasingly preoccupied with betting; needs to increase the size of wagers to achieve the desired psychological effects; and finds that efforts to control, reduce, or stop gambling are unsuccessful. The pathological gambler characteristically gambles increasing amounts to try to win back lost money ("chasing losses"). ${ }^{11}$

Gambling and the need for money with which to place bets interferes with other activities and personal relationships. The gambler may lie to conceal losses and steal money from family members and employers, rationalising this behaviour as temporary borrowing. Denial is typically used as a defence mechanism, as it is in other addictions. Restlessness, irritability, and somatic symptoms may occur when gambling is interrupted. Physical symptoms characteristically thought of as related to stress are common, as are comorbid psychoactive disorders such as suicidal depression. ${ }^{11}$

Treatment consists of a combination of professional and self help (Gamblers Anonymous, and Gamanon for families), and long term follow up is essential. Members of a pathological gambler's family also need help. Pathological gambling can usually be treated on an outpatient basis. Inpatient treatment in an addiction facility has also been found successful. ${ }^{12}$ Commonly used treatments include psychoeducation; individual, group, and family counselling; stress management; relapse prevention; and referral to Gamblers Anonymous.

As Britain liberalises its gambling laws doctors should become informed about pathological gambling and its medical, social, and psychological consequences. There is scant professional recognition of pathological gambling and little in the way of organised treatment or research. A patient whose persistent gastrointestinal symptoms relate to uncontrolled gambling will therefore go untreated, and a family destroyed by gambling will be denied professional help. Medical leadership can reverse this trend and help develop the education, treatment, prevention, and research that are needed to confront pathological gambling. As gambling becomes more socially acceptable and more widely available, the need for doctors to tackle the associated problems will become more urgent. 
The telephone number for Gamblers Anonymous in Britain is 01713843040 . In the United States it is (213) 3868789. The number for the toll free information line of the US National Council on Problem Gambling is 1-800-522-4700.

SHEILA B BLUME Medical director

Alcoholism, Chemical Dependency, and Compulsive Gambling Programs,

South Oaks Hospital,

Amityville, NY 11701, USA

1 Clotfelter CT, Cook PJ. Selling hope: state lotteries in America. Cambridge, MA: Harvard University Press, 1989.

2 Dostoyevsky F. The gambler/Bobok/A nasty story. New York: Penguin, 1966:7-16. (Transl J Coulson.)

3 Christiansen EM. The 1992 gross annual wagering of the United States: parts I and II. International Gaming and Wagering Business 1993;14(7):12-33;14(8):12-30.
4 American Psychiatric Association. Diagnostic and statistical manual of mental disorders. 4th ed. Washington, DC: APA, 1994

5 Volberg RA. Prevalence studies of problem gambling in the United States. Foumal of Gambling Studies (in press).

6 Lesieur HR, Blume SB, Zoppa RM. Alcoholism, drug abuse and gambling. Alcohol Clin Exp Res 1986;10:33-8.

7 Lesieur HR, Heineman M. Pathological gambling among youthful multiple substance abusers in a therapeutic community. Br f Addict 1988;83:765-71.

8 Lesieur HR, Blume SB. The South Oaks gambling screen (SOGS): a new instrument for the identification of pathological gamblers. Am $\mathcal{F}$ Psychiatry 1987;144:1184-8.

9 Lesieur HR, Blume SB. Revising the South Oaks gambling screen in different settings. Fournal of Gambling Behavior 1992;9:213-9.

10 Roy A, Adinoff B, Roehrick L, Lamparski D, Custer R, Lorenz V, et al. Pathological gambling: a psychobiological study. Arch Gen Psychiatry 1988;45:369-73.

11 Lesieur HR, Rosenthal RJ: Pathological gambling: a review of the literature (prepared for the American Psychiatric Association Task Force on DMS-IV Committee on Disorders of Impulse American Psychiatric Association Task Force on DMS-IV Committee on
Control Not Elsewhere Classified). Foumal of Gambling Studies 1991;7:5-39.

12 Lesieur HR, Blume SB. Evaluation of patients treated for pathological gambling in a combined alcohol, substance abuse and pathological gambling treatment unit using the addiction severity index. Brf Addict 1991;86:1017-28.

\section{Letter fraud}

\section{Easy to commit, hard to detect}

Recently we published a letter from a Dr James Bird, consultant physician at St Mary's Hospital, London. ${ }^{1}$ Although the letter was signed and came on headed notepaper, we learnt that no such doctor has ever worked at St Mary's and his name is not listed in the Medical Directory or the Medical Register. We have therefore retracted the letter ( $\mathrm{p} 573$ ).

Ironically Dr Bird's letter was written in response to an editorial by Richard Smith on academic integrity. ${ }^{2}$ The BMFs policy is that conflicts cannot be eradicated but should always be disclosed, ${ }^{34}$ and we now publish the source of funding for all research papers and require all authors of editorials and papers, all referees, and the authors of some letters to declare any conflict of interest. Dr Bird disputed the need for such declarations in scientific journals. He wrote: "Editors of journals have the responsibility to ensure that material that is published is soundly based, conducted, and interpreted; if it is, then the source of funding is immaterial. If editors have any doubts about any of these then they do not publish the paper; again, the source of funding is immaterial."

We do not agree. Papers do not divide neatly into good and bad: rather they form a spectrum from good to bad-with many clustering around the middle. And there is abundant evidence that conflict of interest influences the kind of research done and how it is interpreted. ${ }^{45}$

Dr Hugh Baron, a consultant gastroenterologist at $\mathrm{St}$ Mary's Hospital, alerted the $B M \mathcal{F}$ to the non-existence of $\mathrm{Dr}$ Bird. $\mathrm{He}$ and his colleagues felt that they had been depicted as fools or knaves: fools, because they would take money from anyone without being influenced, and knaves, because they would take money from anyone and be influenced. There is no apparent reason why the author might want to be identified with St Mary's Hospital-the hospital has never taken a view on statements of conflict of interest. We can never be sure of the author's motives for sending the letter, but there may be an undeclared conflict of interest.

Publication of a critical letter in itself is not the problem, but the reader should know if the author is backed by a particular player, such as the pharmaceutical industry. Drummond Rennie, deputy editor of $\mathscr{f} A M A$, said that the problem lies in the subsequent use made of such letterssomething an editor often has to consider, especially since many people believe that publication implies some sort of endorsement. ${ }^{6}$

Famous examples of fraudulent letters are the outraged letter the Daily Telegraph from an outraged "Edna Welthorpe" and "Donald H Hartley," which were written by Joe Orton to publicise his play Entertaining $\mathrm{Mr}$ Sloane. Other well known examples come from Henry Root, who became famous for writing to the great and the good with extraordinary and fake requests for services, publishing the replies in bestselling books. ${ }^{7}$ Both these masquerades were relatively harmless.

More recently, $\mathcal{f} A M A$ received a letter from Theodore $\mathrm{H}$ Fiddleman, which was critical of a study it had published correlating tobacco firms' campaign contributions and legislation in favour of the industry. Fiddleman has now been exposed as an invention of Paul $\mathrm{H}$ Blackman, research coordinator for the National Rifle Association's lobbying and research arm. ${ }^{8}$ Blackman admitted to a string of essays and letters published since the 1970s under Fiddleman's name. $\mathcal{F} A M A$ fortunately uncovered the fraud before publication; Blackman's writing style had been recognised. Blackman defended his action, arguing that it was easier to get letters published if he did not identify his affiliation. He had, he said, developed the tactic to get pieces against gun control published because so many letters had been published under his own name that editors had declined to print more. He said: "In a sense, I have enhanced honesty by letting people read a letter without the public saying, 'Oh, the NRA, let's dismiss this." "

Another way to publish a fraudulent letter is by using someone else's name. The Independent recently published a letter from Ted Honderich, Groate professor of the philosophy of mind and body at University College, London. ${ }^{9}$ Professor Honderich had been impersonated, and the Independent published a correction the next day. ${ }^{10}$

The $B M 7$ receives 80 to 90 letters a week. It is a large task to process these and would be considerably larger if every letter's authenticity was called into question. In addition, approaching any article primarily with fraud in mind may threaten the mutual trust on which science has always depended. ${ }^{11}$

We publish about a third of all the letters we receive and currently contact about half of these authors to ask for amendments or further information. Dr Bird's letter was published in the $B M \mathcal{F}$ without our needing to make contact with him. Had we asked him to sign a statement about conflict of interest his fraud would then have been exposed.

It is remarkably easy to publish a fraudulent letter, and many newspapers have attempted to address the problem. iSeveral of the British dailies ask for a daytime telephone number, and the Times verifies all accepted letters by telephoning the author. Matthew Hoffman, letters editor at 